NOTE

\title{
Chytridiomycosis in two species of Telmatobius (Anura: Leptodactylidae) from Argentina
}

\author{
Sebastián Barrionuevo ${ }^{1, *}$, Susana Mangione ${ }^{2}$ \\ ${ }^{1}$ Instituto de Herpetología and ${ }^{2}$ Instituto de Morfología Animal, Fundación Miguel Lillo, Miguel Lillo 251 (4000) Tucumán, \\ Argentina
}

\begin{abstract}
Dead specimens of Telmatobius atacamensis and T. pisanoi were found in 2 localities in northwestern Argentina. The diagnosis was positive for chytridiomycosis caused by Batrachochytrium dendrobatidis. Zoosporangia were identified in different stages: immature, mature with zoospores, empty and collapsed. This is the second report of chytridiomycosis in Argentina but the first one involving highly endangered species.
\end{abstract}

KEY WORDS: Chytridiomycosis $\cdot$ Telmatobius $\cdot$ Argentina

Resale or republication not permitted without written consent of the publisher

\section{INTRODUCTION}

In the last few decades, declines in population and extinctions have been reported worldwide for several species of amphibian (Crump et al. 1992, Carey 1993, Laurence 1996, Lips 1998, Houlahan et al. 2000). Many population declines have occurred even in pristine areas where human impact is minimal. Different causes have been proposed, including global climate change, increasing incidence of UV-B radiation, habitat alteration, introduction of exotic species and emerging diseases (Young et al. 2001). Chytridiomycosis has been linked to amphibian declines mainly in Australia and Central and South America as well as in North America and Europe (Berger et al. 1999a, Bosch et al. 2001, Bradley et al. 2002, Ron et al. 2003, Burrowes et al. 2004, Lips et al. 2006). This disease is caused by Batrachocyitrium dendrobatidis (Phylum Chytridiomycota, Class Chytridiomycetes, Order Chytridiales), a protein degrader fungus (Piotrowski et al. 2004) that affects the stratum corneum and the stratum granulosum of amphibian skin. Since its discovery in 1998 (Berger et al. 1998) the fungus has been detected in a broad range of amphibian species worldwide (Speare \& Berger 2000). Since B. dendrobatidis morphology is conspicuous and clearly differs from the normal epidermal structures, the diagnosis of chytrid- iomycosis can be easily carried out by examining histopathological changes in the skin.

Approximately 60 species of frogs in the genus Telmatobius inhabit aquatic habitats in high mountain ranges, from Ecuador to Argentina and Chile. There are 2 previous reports of chytridiomycosis for the genus: Telmatobius niger from Ecuador (Merino-Viteri et al. 2005) and T. marmoratus from Peru (Seimon et al. 2005). Here we report the presence of chytridiomycosis in 2 Argentinean species of the genus Telmatobius whose population status is stated as critical (IUCN et al. 2006, S. Barrionuevo \& M. L. Ponssa unpubl. data).

\section{MATERIALS AND METHODS}

Two dead specimens of Telmatobius atacamensis (Fundación Miguel Lillo [FML] 16932, 16933) and one live specimen (FML 16931) were collected on 23 November 2003 from Los Patos (2414' 50" S, 66 13' 57.9" W, 3885 m), Salta Province, in northern Argentina (Fig. 1). One dead specimen of $T$. pisanoi (FML 16934) was collected on 20 May 2005 in a subsidiary stream of the River Los Zarzos $\left(26^{\circ} 21^{\prime} 11.7^{\prime \prime} \mathrm{S}\right.$, $66^{\circ} 02^{\prime} 45.2^{\prime \prime} \mathrm{W}, 2352 \mathrm{~m}$ ) near the town of El Pichao, Tucumán Province, Northern Argentina (Fig. 1). 


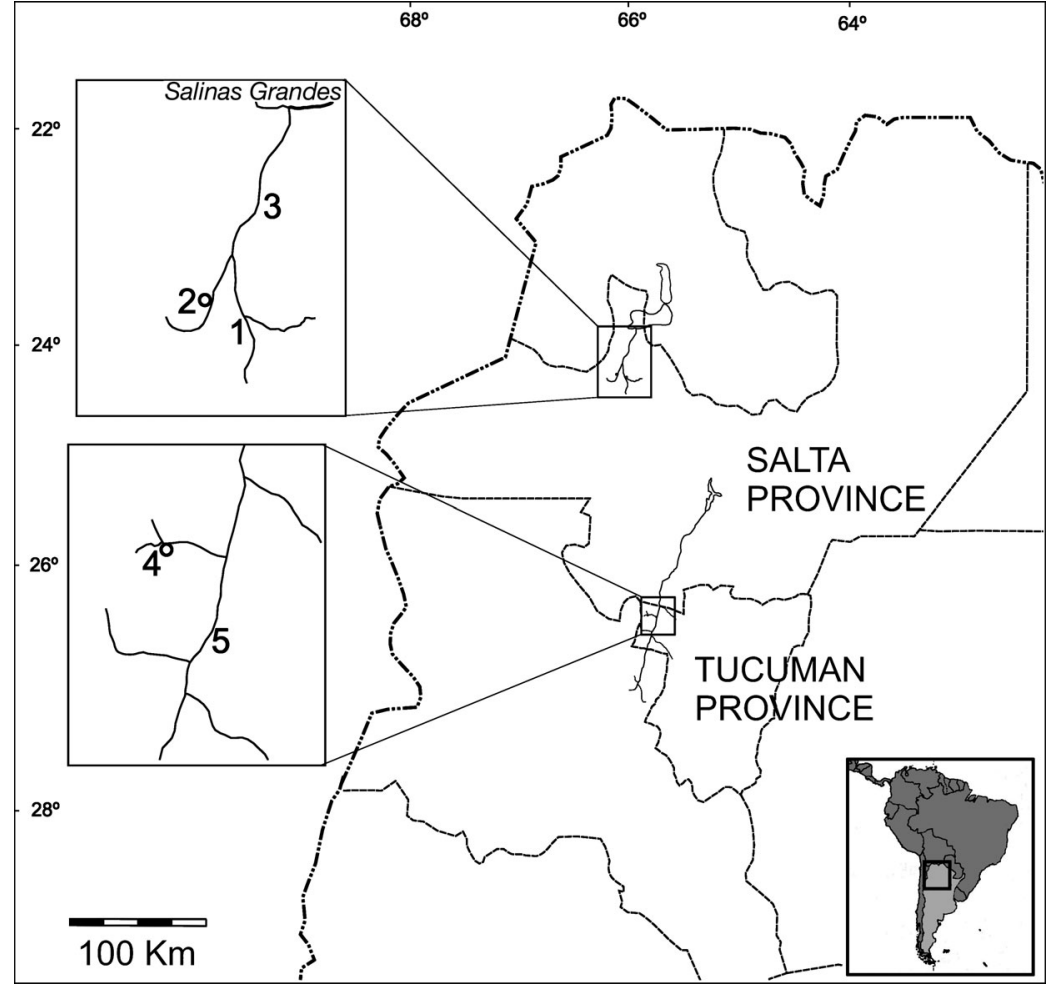

Fig. 1. Northwestern Argentina. 1: Los Patos; 2: San Antonio de Los Cobres; 3: River San Antonio de Los Cobres; 4: El Pichao; 5: River Santa María sporangia. Immature zoosporangia containing granular basophilic and eosinophilic material surrounded by a clear matrix were also observed.

The zoosporangial morphology matches the descriptions of the chytrid fungus Batrachochytrium dendrobatidis provided in previous works (Berger et al. 1999b, Pessier et al. 1999). The absence of chytrid fungus in one specimen of Telmatobius atacamensis (FML 19633) may be the result of an incomplete histological exploration (a false negative), as the zoosporangia are not evenly distributed in the skin but are often closely clustered (Piotrowski et al. 2004).

Although some portions of the stratum corneum were thickened, hyperkeratosis was not observed in any of the examined specimens. In the most heavily infected specimen (Telmatobius atacamensis, FML 16932), the stratum corneum, which contained high numbers of empty zoosporangia, was present as sloughed skin. In another specimen of $T$. atacamensis (FML 16931), an inflammatory process was evident by the presence of blood
The specimens were fixed in the field in $10 \%$ neutral buffered formaldehyde. Ventral skin samples from thighs and toe clips were collected for examination. Standard histological techniques for light microscopy were applied, the samples were sectioned at $6 \mu \mathrm{m}$, stained with haematoxylin and eosin, and examined at $40 \times$ and $100 \times$ magnification. For chytrid identification, the procedures described by Berger et al. (1999b) and Pessier et al. (1999) were followed.

\section{RESULTS}

We identified a fungal skin infection in 3 of the 4 specimens. Different stages of zoosporangia in the stratum corneum and stratum granulosum were identified. Mature zoosporangia were round, ranging from 6 to $10 \mu \mathrm{m}$ in diameter, with a thin wall (Fig. 2) and contained rounded basophilic zoospores 1 to $2 \mu \mathrm{m}$ in diameter. The spores were observed exiting the zoosporangia via a discharge tube formed by an evagination of the zoosporangium wall. The empty postdischarge zoosporangia were the most frequently observed stages in the stratum corneum, with most exhibiting a spherical appearance and others collapsed. Characteristic septa were observed in some

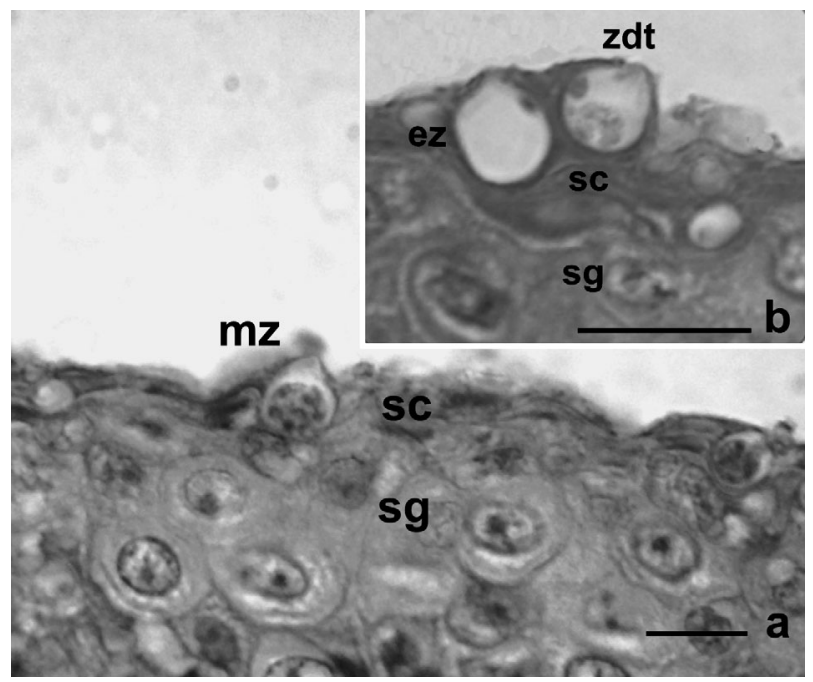

Fig. 2. Telmatobius atacamensis skin sections. (a) Ventral thigh. Note mature zoosporangium $(\mathrm{mz})$ in the stratum corneum (sc). Zoospores can be distinguished within the zoosporangia; sg: stratum granulosum. Scale bar $=11 \mu \mathrm{m}$. (b) Finger skin. Two mature zoosporangia projecting outside discharge tubes (zdt) in the sc. The one on the right is discharging zoospores, whereas the other one is almost empty (ez). Scale bar $=19 \mu \mathrm{m}$ 
cells and lymphocytes in the stratum spinosum. The skin of the T. pisanoi specimen (FML 16934) was in an advanced state of decomposition, which precluded examination by histopathology.

Finally, none of the specimens analysed in this study displayed any clinical or behavioural abnormalities at the time of collection.

\section{DISCUSSION AND CONCLUSIONS}

This is the second report of chytridiomycosis in Argentina. The first case was detected in the Province of Buenos Aires (Herrera et al. 2005), in Leptodactylus ocellatus, a common species of the pampas batrachofauna. Here we report the first record of chytridiomycosis involving an endangered species within this country.

The role of chytridiomycosis in global amphibian decline is controversial. McCallum (2005) stated that the proposition of chytridiomycosis as the principal cause of amphibian declines is not conclusive. In postdecline populations of Taudactylus eungellensis and populations of Litoria wilcoxi from Australia, infections of Batrachochytrium dendrobatidis persist with no signs of new declines, suggesting the achievement of some host-pathogen equilibrium (Retallick et al. 2004). Alternately, other authors have argued that there is a clear link between chytridiomycosis and amphibian population declines (Daszak et al. 2003). Pounds et al. (2006) suggested that global warming is changing atmospheric conditions and that temperatures of many highland localities are now approaching the thermal optimum for the reproduction of $B$. dendrobatidis thereby favouring outbreaks of chytridiomycosis.

Daszak et al. (2003) proposed a scenario to explain the differential impact of chytridiomycosis on amphibian species. In a pyramid relating host ecology traits with chytrid biology, different combinations of those parameters result in a higher or lower impact of chytridiomycosis on amphibian populations. Host ecology traits that produce a major impact include naivety, high altitude distribution, low fecundity rates, high water dependence and habitat specialisation. In this context, Telmatobius species would be vulnerable to Batrachochytrium dendrobatidis infection because they have the following ecological traits: (1) Aquatic mode of life. (2) Distribution in high mountain ranges; the species of Telmatobius live between approximately 1000 and $4500 \mathrm{~m}$ (De la Riva 2005). (3) Low fecundity; although scarce, there is some information on the reproductive biology of Telmatobius. The reports of clutch size vary from 80 (T. laticeps, Pisanó 1955) to about 500 eggs per clutch (T. culeus, Pérez 1998; T. laticeps, R. Montero pers. comm.). These numbers are considered low compared to other species that lay eggs and whose larvae complete their development in water (Crump 1974). (4) Endemic distribution; many species of Telmatobius are known only from their typical location, and others have very small distribution areas such as isolated heads of streams.

In Ecuador, chytridiomycosis and an abnormal climate pattern could have caused the decline and extinction of the species of Telmatobius (Merino-Viteri et al. 2005). The disease was detected in 1989 in T. niger, the most widespread species of Telmatobius in that country. No T. niger was seen after 1994. Two other species had also previously disappeared: $T$. vellardi in 1987 and T. cirrhacelis in 1981 (Merino-Viteri et al. 2005). Chytridiomycosis has also been implicated as one of the causes of the extinction of several species of the genus Atelopus in Ecuador (Bustamante et al. 2005). In Peru, chytridiomycosis has been detected recently in T. marmoratus at almost $4500 \mathrm{~m}$ (Seimon et al. 2005); although there are diverse indications of a decline of Telmatobius in that country, no empirical data are available to support this hypothesis.

In Argentina, Telmatobius atacamensis has been categorized as a species 'in critical danger of extinction' (IUCN et al. 2006). It is likely that this species is now extinct at its previously reported locality in the vicinity of the town of San Antonio de Los Cobres (Lavilla \& Cei 2001). A new population was discovered in recent years at the River Los Patos, a tributary of the River San Antonio de Los Cobres (IUCN et al. 2006). The second species, T. pisanoi, is considered 'in danger' (IUCN et al. 2006). Exhaustive surveys carried out between 2002 and 2005 indicate that this species has disappeared from most parts of its original distribution area (S. Barrionuevo \& M. L. Ponssa unpubl. data). At present there are 2 remnant populations at the edge of its distribution area that seem to be small and fragile.

Our results suggest that chytridiomycosis was the cause of death for the specimens described in this study. At this point, however, we cannot conclude that chytridiomycosis is responsible for the population declines of these 2 Argentinean Telmatobius species. Nevertheless, the detection and reporting of chytridiomycosis for these critically endangered species is the first step toward resolving the cause(s) of the population declines.

Acknowledgements: We thank M. L. Ponssa, M. Mirande, A. Novillo, M. I. Martinez Oliver, G. Aguilera and G. Suarez for field assistance; and R. Montero for revising this manuscript. Telmatobius pisanoi samples were collected with the support of a DAPTF seed grant 2004 to S.B. for monitoring Telmatobius populations in Tucumán Province. 


\section{LITERATURE CITED}

Berger L, Speare R, Daszak P, Green DE and 10 others (1998) Chytridiomycosis causes amphibian mortality associated with population declines in the rain forests of Australia and Central America. Proc Natl Acad Sci USA 95: 9031-9036

Berger L, Speare R, Hyatt A (1999a) Chytrid fungi and amphibian declines: overview, implications and future directions. In: Campbell A (ed) Declines and disappearances of Australian frogs. Environment Australia, Canberra, p 23-33

Berger L, Speare R, Kent A (1999b) Diagnosis of chytridiomycosis in amphibians by histologic examination. Available at: www.jcu.edu.au/school/phtm/PHTM/frogs/histo/ chhisto.htm, 20 Nov 1999

Bosch J, Martinez-Solano I, Garcia-Paris M (2001) Evidence of a chytrid fungus infection involved in the decline of the common midwife toad (Alytes obstetricans) in protected areas of Central Spain. Biol Conserv 97:331-337

Bradley GA, Rosen PC, Sredl MJ, Jones TR, Longcore JE (2002) Chytridiomycosis in native Arizona frogs. J Wildl Dis 38(1):206-212

Burrowes PA, Joglar RL, Green DE (2004) Potential causes for amphibian declines in Puerto Rico. Herpetologica 60(2): $141-154$

Carey C (1993) Hypothesis concerning the causes of the disappearance of boreal toads from the mountains of Colorado. Conserv Biol 7 (2)355-362

Crump ML (1974) Reproductive strategies in a tropical anuran community. Misc Publ Mus Nat Hist Univ Kans (61): $1-68$

Crump ML, Hensley FR, Clark KL (1992) Apparent decline of the golden toad: underground or extinct? Copeia 1992 (2): 413-420

Daszak P, Cunningham AA, Hyatt AD (2003) Infectious disease and amphibian population declines. Divers Distrib 9: 141-150

De la Riva I (2005) Bolivian frogs of the genus Telmatobius (Anura: Leptodactylidae): synopsis, taxonomic comments, and description of a new species. In: Lavilla EO, De la Riva I (eds) Studies on the Andean frogs of the genera Telmatobius and Batrachophrynus. Monografías de Herpetología 7, Asociación Herpetológica Española, Valencia, p 65-101

Herrera RA, Steciow MM, Natale GS (2005) Chytrid fungus parasitizing the wild amphibian Leptodactylus ocellatus (Anura: Leptodactylidae) in Argentina. Dis Aquat Org 64: 247-252

Houlahan JE, Findlay CS, Schmidt BR, Meyer AH, Kuzmin SL (2000) Quantitative evidence for global amphibian population declines. Nature 404:752-755

IUCN (International Union for Conservation of Nature and Natural Resources), Conservation International, and NatureServe. (2006) Global amphibian assessment. Available at: www.globalamphibians.org, 4 June 2006

Laurance WF, McDonald KR, Speare R (1996) Epidemic dis-

Editorial responsibility: Alex Hyatt,

Geelong, Victoria, Australia ease and the catastrophic decline of Australian rain forest frogs. Conserv Biol 10(2):406-413

Lavilla EO, Cei JM (2001) Amphibians of Argentina. A second update, 1987-2000, Torino, Italy. Monogr Mus Reg Sci Nat 28:1-177

Lips KR (1998) Decline of a tropical montane amphibian fauna. Conserv Biol 12:106-117

Lips KR, Brem F, Brenes R, Reeve JD and 6 others (2006) Emerging infectious disease and the loss of biodiversity in a Neotropical amphibian community. Proc Natl Acad Sci USA 102:3165-3170

McCallum H (2005) Inconclusiveness of chytridiomycosis as the agent in widespread frog declines. Conserv Biol 19(5): 1421-1430

Merino-Viteri A, Coloma LA, Almendáriz A (2005) Los Telmatobius de los Andes de Ecuador y su disminución poblacional. In: Lavilla EO, De la Riva I (eds) Studies on the Andean frogs of the genera Telmatobius and Batrachophrynus. Monografías de Herpetología 7, Asociación Herpetológica Española, Valencia, p 9-37

Pérez ME (1998) Dieta y ciclo gametogénico anual de Telmatobius culeus (Anura, Leptodactylidae) en el Lago Titicaca (Huiñaimarca). Tesis de Licenciatura, Universidad Mayor de San Andrés, La Paz

Pessier AP, Nichols DK, Longcore JE, Fuller MS (1999) Cutaneous chytridiomycosis in poison dart frogs (Dendrobates spp.) and White's tree frogs (Litoria caerulea). J Vet Diag Invest 11:194-199

Piotrowski JS, Annis SL, Longcore JC (2004) Physiology of Batrachochytrium dendrobatidis, a chytrid pathogen of amphibians. Mycologia 96(1):9-15

Pisanó A (1955) Notas ecológicas sobre la vida larvaria de Telmatobius schreiteri. Cienc Invest 11(2):86-91

Pounds AJ, Bustamante MR, Coloma LA, Consuegra JA and 10 others (2006) Widespread amphibian extinctions from epidemic disease driven by global warming. Nature 439: 161-167

Retallick RWR, McCallum H, Speare R (2004) Endemic infection of the amphibian chytrid fungus in a frog community post-decline. PLoS Biol 2(11):1965-1971

Ron SR, Duellman W, Coloma LA, Bustamante M (2003) Population decline of the Jambato toad Atelopus ignescens (Anura: Bufonidae) in the Andes of Ecuador. J Herpetol 37 (1):116-126

Seimon, TA, Hoernig G, Sowell P, Halloy S, Seimon A (2005) Identification of chytridiomycosis in Telmatobius marmoratus at $4450 \mathrm{~m}$ in the Cordillera Vilcanto of Southern Peru. In: Lavilla EO, De la Riva I (eds) Studies on the Andean frogs of the genera Telmatobius and Batrachophrynus. Monografías de Herpetología 7, Asociación Herpetológica Española, Valencia, p 273-281

Speare R., Berger L (2000) Global distribution of chytridiomycosis in amphibians. Available at: http://www.jcu.edu. au/school/phtm/PHTM/frogs/chyglob, 11 Nov 2000

Young BE, Lips KR, Reaser JK, Ibáñez R and 10 others (2001) Population declines and priorities for amphibian conservation in Latin America. Conserv Biol 15:1213-1223

Submitted: July 9, 2006; Accepted: October 3, 2006

Proofs received from author(s): November 17, 2006 